\title{
Wiedza w ręku. Wiedza niedyskursywna i czucie ciała pacjenta w zawodzie terapeuty manualnego
}

\author{
Ariel Modrzyk \\ Uniwersytet im. Adama Mickiewicza w Poznaniu
}

DOI: http://dx.doi.org/10.18778/1733-8069.16.2.08

\section{Słowa kluczowe: wiedza niedyskursywna, dotyk, terapeuci manualni, fizjoterapia, metody jakościowe}

\begin{abstract}
Abstrakt: Czucie ciała pacjenta jako część profesji terapeutów manualnych to tematyka powiązana z pojęciem wiedzy niedyskursywnej. Podstawowym celem artykułu jest przybliżenie czytelnikowi tych zagadnień jako swoistego pomostu, który pozwala interdyscyplinarnie łączyć nauki społeczne z naukami o zdrowiu. Cel ten zakłada przede wszystkim uświadomienie istnienia pewnego elementu wiedzy fizjoterapeutycznej, który - wbrew temu, czego wymaga dominująca w naukach medycznych zobiektywizowana forma prezentacji wiedzy i badań - łatwo nie poddaje się językowemu wyjaśnieniu i kwantyfikacji. Wraz z tym założeniem najważniejszymi kwestiami, na których koncentruje się artykuł, są: uwrażliwienie na bariery, na jakie napotykają badacze próbujący badać zjawisko czucia ciała pacjenta przy użyciu metod jakościowych; przedstawienie tego, czym jest kompetencja czucia ciała pacjenta; w jaki sposób się jej naucza i ją nabywa oraz w jaki sposób problematyzuje ona dominujące standardy naukowości w naukach medycznych.
\end{abstract}

Ariel Modrzyk, doktor nauk społecznych, fizjoterapeuta, adiunkt w Instytucie Socjologii Uniwersytetu im. Adama Mickiewicza. Autor licznych publikacji w opracowaniach zbiorowych oraz czasopismach oraz dwóch monografii. Zainteresowania naukowe: socjologia życia codziennego, teoria socjologiczna, socjologia jedzenia, socjologia ciała, posthumanizm.

\author{
Adres kontaktowy: \\ Wydział Socjologii \\ Uniwersytet im. Adama Mickiewicza w Poznaniu \\ ul. Szamarzewskiego 89, budynek C \\ 60-568 Poznań \\ e-mail: arlmodrzyk@gmail.com
}




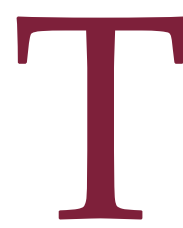

erapeuci manualni tym różnią się od wielu profesji medycznych (np. chirurgów, ortopedów, stomatologów, pielęgniarek), że z zasady nie ingerują w ciało pacjenta poprzez jego otwarcie. Poza pewnymi wyjątkami (stosowanie pijawek, igłoterapia) ich działanie polega na stosowaniu dotyku oraz poruszaniu tkankami z zewnątrz, aby wytworzyć efekt wewnętrzny w ciele pacjenta. Ponadto ich działanie polega na holistycznym spojrzeniu na ciało człowieka i szukaniu zależności przyczynowo-skutkowych pomiędzy różnymi częściami układu ruchu (np. relacja między bólem szyi a napięciami w stopach) oraz pomiędzy poszczególnymi układami (wzajemny wpływ układu ruchu i organów wewnętrznych), co stoi w sprzeczności z silną specjalizacją lekarzy. Jeżeli chodzi o sektor terapeutyczno-leczniczy, zarówno lekarze, jak i terapeuci manualni pracują bezpośrednio, dotykając ciała pacjenta, czym różnią się od psychologów, którzy poza pewnymi nurtami (Lowen 1991; 2011) zazwyczaj próbują pomóc poprzez samą rozmowę i wywiad.

Czucie ciała pacjenta (dalej CCP) wśród terapeutów manualnych to tematyka powiązana $\mathrm{z}$ pojęciem wiedzy niedyskursywnej. Podstawowym celem artykułu jest przybliżenie czytelnikowi tych zagadnień jako swoistego pomostu, który pozwala interdyscyplinarnie łączyć nauki społeczne z naukami o zdrowiu. Cel ten zakłada przede wszystkim uświadomienie istnienia pewnego elementu wiedzy fizjoterapeutycznej, który wbrew temu, czego wymaga dominująca w naukach medycznych zobiektywizowana forma prezentacji wiedzy i badań, łatwo nie poddaje się językowemu wyjaśnieniu i kwantyfikacji. Tematyka CCP została zbadana przy użyciu jakościowych metod badawczych nauk społecznych, takich jak wywiady pogłębione oraz autoetnografia. Dlatego też drugim celem artykułu jest pokazanie potencjału tego typu metod w badaniach takich dziedzin wiedzy jak fizjoterapia i nauki medyczne. Wykorzystanie metod badań jakościowych nie tylko jest korzystne dla przedstawicieli nauk społecznych (zdobywanie nowej wiedzy i rozwijanie własnej teorii i pojęć), ale również pozwala na lepsze zrozumienie swojej praktyki przez przedstawicieli świata medycznego. Trzymając się zagadnienia CCP, należy uznać, że pod tym względem jest to temat istotny, ponieważ nie jest odpowiednio dostrzegany na studiach i w materiałach szkoleniowych z zakresu fizjoterapii, a jednocześnie ma niebagatelne znaczenie dla efektywności procesu leczenia pacjenta. Na pewno już samo uświadomienie sobie funkcji tej umiejętności $\mathrm{w}$ całym procesie terapeutycznym i ciągłe zwracanie uwagi na ten aspekt może przyczynić się do polepszenia warsztatu terapeutycznego początkującego terapeuty manualnego. Oczywiście nie wystarczy zaklinać rzeczywistości, mówiąc "Wiem, że to jest ważne”. Konieczne jest również przemyślenie tego, jak przekazywać taką wiedzę i ją nabywać.

Skupiając się stricte na punkcie widzenia przedstawicieli nauk społecznych, badanie CCP w zawodzie terapeuty manualnego jest kolejnym polem badawczym, które dostarcza nam cząstkowej wiedzy na temat wiedzy niedyskursywnej. Badając takie różnorodne obszary jej przejawiania się jak rzemiosło, sport, doświadczenie zmysłowe (np. zapachy i smak podczas gotowania potraw), możemy dokonać próby powiedzenia czegoś nowego i bardziej ogólnego na temat pojęcia wiedzy niedyskursywnej. Dlatego prezentowany tekst będzie stanowił użyteczne źródło wiedzy nie tylko dla socjologów nauki, ale również dla badaczy wiedzy niedyskursywnej, zmysłowej i dotykowej (Howes 2005; Krajewski 2005; Obrador 2012; Vannini, Waskul, Gottschalk 2012). 
Ostatnim celem artykułu jest przybliżenie czytelnikom niemającym specjalistycznej wiedzy medycznej $\mathrm{z}$ zakresu fizjoterapii specyfiki zawodu terapeuty manualnego, którego znacznie społeczne jest ważne, biorąc pod uwagę dane wskazujące na starzenie się społeczeństw na całym świecie, skutkujące tym, że w przyszłości zdecydowana większość osób starszych będzie wymagała pomocy przedstawiciela tego zawodu.

W dalszych fragmentach tekstu najważniejszymi kwestiami, na których się skupiam, są: przedstawienie tego, czym jest kompetencja CCP, w jaki sposób się jej naucza i ją nabywa oraz $\mathrm{w}$ jaki sposób problematyzuje ona dominujące standardy naukowości w naukach medycznych. Zanim przejdę do przedstawienia tych zagadnień, chciałbym zarysować metodologię badań oraz pojęcie wiedzy niedyskursywnej.

\section{Metodologia badania}

Opis kompetencji czucia ciała w zawodzie terapeuty manualnego opieram na dziesięciu wywiadach pogłębionych przeprowadzonych w 2019 roku z terapeutami manualnymi. Niniejsze badanie odnosiło się do następujących problemów badawczych.

- W jaki sposób respondenci próbowali zwerbalizować tak subiektywne zjawisko jak CCP? W jakim stopniu da się opisać własne subiektywne doświadczenia za pomocą języka?

- W jaki sposób respondenci nabywali i rozwijali kompetencję CCP?

- W jaki sposób można nauczać inne osoby kompetencji CCP, w tym początkujących fizjoterapeutów?
- Jak jest traktowana kompetencja CCP w obliczu innych, bardziej podatnych na kwantyfikację i standaryzację metod? Jakie są granice, po przekroczeniu których kończy się profesja oparta na nauce, a zaczyna się „,szarlataństwo”? Jakie są różnice pod tym względem między fizjoterapeutami manualnymi a osteopatami?

Określenie terapeuta manualny będzie zbiorczo odnosiło się do przedstawicieli różnych szkół terapii manualnej w fizjoterapii (5 wywiadów) oraz osteopatów (5 wywiadów). Jest to do pewnego stopnia podział sztuczny, ponieważ zarówno fizjoterapeuci, jak i osteopaci są terapeutami manualnymi. Mianem terapeutów manualnych możemy określać osoby próbujące wyleczyć pacjenta przy pomocy pracy rąk, takiej jak masaż, nacisk oraz manipulowanie tkankami. Wszyscy terapeuci manualni są jednocześnie fizjoterapeutami, którzy w tym kontekście są najszerszą kategorią zawodową, obejmującą poza terapeutami manualnymi trenerów funkcjonalnych, rehabilitantów w szpitalach oraz osoby pracujące $\mathrm{z}$ osobami z głęboką niepełnosprawnością. Zatem osteopaci są również fizjoterapeutami, ponieważ warunkiem uczenia się w szkołach osteopatycznych jest fakt posiadania tytułu magistra fizjoterapii. Mając na uwadze arbitralność tego podziału, rozróżniam terapeutów manualnych fizjoterapeutów oraz terapeutów manualnych osteopatów, ponieważ zazwyczaj taki podział istnieje w środowisku zawodowym. Wynika on w szczególności ze specyfiki i filozofii pracy osteopatów, którzy posługują się wieloma skutecznymi, ale jednocześnie niepotwierdzonymi naukowo technikami terapeutycznymi. Sami osteopaci odróżniają się od pozostałych terapeutów manualnych, ponieważ ich specjalizacja wymaga ukończenia kilkuletniej szkoły, w której znacznie poszerzona jest wiedza z zakresu anatomii i fizjologii ciała człowieka w porównaniu do studiów magisterskich z zakresu fizjoterapii. 
Tabela 1. Informacje o respondentach biorących udział w badaniu.

\begin{tabular}{|c|c|c|c|c|}
\hline Lp. & Specjalizacja & Płeć & $\begin{array}{c}\text { Szczegółowe informacje na temat } \\
\text { specjalizacji }\end{array}$ & $\begin{array}{c}\text { Doświadczenie } \\
\text { w przedziałach } \\
\text { 0-5 lat; 5-10 lat; } \\
\text { 10-15 lat; powyżej } 15 \text { lat }\end{array}$ \\
\hline 1 & Terapeuta manualny & Mężczyzna & $\begin{array}{l}\text { FDM (Fascial Distirtion Model), } \\
\text { fizjoterapia ortopedyczna }\end{array}$ & Powyżej 15 lat \\
\hline 2 & Terapeuta manualny & Kobieta & Neurologia dziecięca, onkologia & 5-10 lat \\
\hline 3 & Terapeuta manualny & Mężczyzna & Manipulacje powięziowe Stecco & 10-15 lat \\
\hline 4 & Terapeuta manualny & Kobieta & $\begin{array}{l}\text { Szeroko rozumiana terapia manualna, } \\
\text { terapia Kalherborna }\end{array}$ & Powyżej 15 lat \\
\hline 5 & Terapeuta manualny & Kobieta & $\begin{array}{l}\text { Fizjoterapia ortopedyczna, terapia } \\
\text { Kalherborna }\end{array}$ & $0-5$ lat \\
\hline 6 & Osteopata & Mężczyzna & Chiropraktyka, osteopatia & 10-15 lat \\
\hline 7 & Osteopata & Kobieta & Osteopatia & $5-10$ lat \\
\hline 8 & Osteopata & Mężczyzna & Ostepatia, terapia punktów spustowych & 10-15 lat \\
\hline 9 & Osteopata & Mężczyzna & Osteopatia & 5-10 lat \\
\hline 10 & Osteopata & Mężczyzna & $\begin{array}{l}\text { Masaż głęboki, uczy się w szkole } \\
\text { osteopatycznej }\end{array}$ & $0-5$ lat \\
\hline
\end{tabular}

Źródło: opracowanie własne.

Wywiady były analizowane przy pomocy metody kondensacji oraz interpretacji sensu (Kvale 2004: 196-199). W dalszej części cytaty będą oznaczane kodami TM (terapeuta manualny) oraz O (osteopata) wraz $\mathrm{z}$ podaniem numeru porządkowego $\mathrm{z}$ tabeli respondentów (np. TM1). Zdania wypowiadane przez badacza będą wyróżnione literę „,B” (badacz). Natomiast wypowiedzi respondentów będą kodowane poprzez literę „, $\mathrm{R}^{\prime \prime}$ (respondent).

Wywiady pogłębione dają możliwość, aby badacz i respondent mogli na bieżąco wyjaśniać zawiłe niuanse praktyki fizjoterapeutycznej związane z tematem badań. Należy jednak zaznaczyć, że ta metoda posiada swoje ograniczenia. Wywiady pogłębione zakładają, że nośnikiem wiedzy jest język, a jak zaznaczono wcześniej, badana czynność jest trudno poddawana werbalizacji. Jest to powodem zakończenia badania na liczbie 10 wywiadów. Na tym etapie został osiągnięty próg nasycenia empirycznego i ostatnie wywiady niewiele wnosiły do otrzymanej wiedzy. Pojawił się on tak szybko, ponieważ tematyka, o której rozmawiano, była związana z wiedzą niedyskursywną, w ograniczonym zakresie przekładalną na język werbalny. Zatem CCP do pewnego stopnia można zrozumieć na poziomie czysto rozumowym poprzez komunikację językową. Jednak głębsze pojęcie jej sensu wymaga 
poczucia, co jest równoznaczne z realną praktyką z ciałem pacjenta. Stąd należy wciągnąć dwa wnioski. Po pierwsze, prezentowana technika badań mimo swoich ograniczeń okazała się narzędziem, które pozwoliło zrozumieć wiele niuansów CCP, które nie były oczywiste i dostępne poznawczo przed rozpoczęciem badania. Być może badanie to nie oddaje w pełni, czym jest CCP, ale przynajmniej jego rezultatem jest podkreślenie wielu elementów pracy fizjoterapeuty, które są trudno dostępne dla kogoś niezaznajomionego z tą profesją. Po drugie, takie metody jak wywiad pogłębiony należałoby uzupełniać innymi, takimi jak autoetnografia oraz obserwacja wraz z wykorzystaniem materiałów wideo (Jakubowska 2015).

Zasadnym wydaje się założenie, że standardowe metody jakościowe mogą napotykać na podobne granice skuteczności w przypadku badania innych obszarów powiązanych z wiedzą niedyskursywną. Nie oznacza to oczywiście, że powinniśmy zaniechać dyskursywnych technik badawczych, ponieważ pomimo swych ograniczeń mogą one poszerzać znacząco wiedzę na temat wiedzy milczącej. Nawet badacze, którzy próbują doświadczyć haptycznie, czym jest CCP, nieuchronnie mierzą się z paradoksem, który polega na tym, że badając wiedzę, co do której istnieje ograniczona liczba słów mogących ją wyrazić i jednocześnie uczynić intersubiektywną, sprawozdanie ze swoich badań ostatecznie muszą ująć w formę językową za pomocą artykułów. Należy zatem prezentowane badanie traktować jako próbę językowego opisu rzeczywistości, która ma w dużej mierze charakter pozajęzykowy. Próba pogłębionej intersubiektywizacji wymagałaby „poczucia" tej wiedzy poprzez praktykę z pacjentem lub własnym ciałem. Zatem jeżeli czytelnicy chcieliby bardziej zagłębić tematykę CCP i ją zrozumieć, musieliby przejść na ten pozajęzykowy poziom.
Jako początkujący praktyk z zakresu terapii manualnej informacje, które uzyskałem od respondentów, konfrontowałem z własnymi doświadczeniami. Należy je jednak traktować jako metodę uzupełniającą, która przede wszystkim miała na celu intersubiektywizację uzyskanych informacji - ich lepsze zrozumienie na poziomie czucia - poprzez własny zmysł dotyku. W przypadku tej wykraczającej poza dyskursywny poziom metody autoetnograficznej badacz również musi poddać się reżimowi językowej formy sprawozdawczości z badań terenowych. Innymi słowy, bariery, o których wspominam, wynikają z rozbieżności między wielozmysłowym sposobem zbierania informacji przez badacza, które ostatecznie muszą zostać przełożone na formę językową, co nieuchronnie zubaża osiągniętą wiedzę. W takiej sytuacji własne haptyczne konfrontacje treści z wywiadów pogłębionych na poziomie językowym nie wnoszą dodatkowych sposobów wyrażania językowego tego, czym jest CCP. Jest to powód tego, że nie będę odnosił się od własnych doświadczeń w dalszych fragmentach tekstu. Nie oznacza to jednak, że badacze CCP oraz podobnych zjawisk powinni zaniechać stosowania tej metody. Była ona narzędziem, które pozwoliło na przygotowanie i przeprowadzenie wywiadów w sposób trafny i pogłębiony. Wspólne doświadczenie dotykowe oraz wiedza teoretyczna pomiędzy badaczem a rozmówcami pozwoliła na lepsze wzajemne zrozumienie językowe. Jest to ważny wniosek dla innych badaczy wiedzy niedyskursywnej, zakładający, że autoetnografia jest instrumentem przygotowującym i niezbędnym do odpowiedniego przeprowadzenia wywiadów pogłębionych, poświęconych tej tematyce.

Status mojej osoby podczas wywiadów trudno jednoznacznie odnieść do standardowego podziału na outsidera i insidera (Merton 1972). Z jednej strony by- 
łem insiderem jako początkujący fizjoterapeuta. Wiedza, którą posiadałem, nie była jednak tak zaawansowana jak u znacznie bardziej doświadczonych w praktyce zawodowej rozmówców. Pozwalała ona na wzajemne zrozumienie i szybkie dekodowanie wyrażeń używanych przez respondentów, które mogłyby być trudne do zrozumienia przez laika. Dzięki niej byłem również wyczulony na pewne szczegółowe aspekty CCP, które byłyby niedostępne dla outsiderów (np. bariery w wyczuwaniu określonych struktur na ciele pacjenta). Outsider mógłby w jeszcze większym stopniu napotkać na ograniczenia dyskursywnej metody badań świata pozadyskursywnego, co sprawiłoby, że uzyskana wiedza miałaby jeszcze bardziej powierzchowny charakter. Z drugiej strony byłem outsiderem, ponieważ asymetria w wiedzy między mną a badanymi sprawiała, że nadal musiałem pogłębiać wiele zagadnień, które dla nich wydawały się oczywiste. Innym aspektem wzmacniającym moją rolę jako outsidera było użycie metodologii i wrażliwości nauk społecznych, a nie nauk o zdrowiu. Ta dwoistość sprawiła, że mógłbym zdefiniować swoją rolę jako będącą pomiędzy rolą insidera i outsidera. Ostatecznie można określić ją jako bycie semi-insiderem.

Materiał badawczy jest dodatkowo oparty na analizie kilku atlasów anatomii palpacyjnej oraz podręczników szkół terapii manualnej, które są używane jako materiały dydaktyczne podczas zajęć, na których ćwiczy się CCP na studiach. Prace te mają wartość uzupełniającą podstawowe źródło danych, czyli wywiady pogłębione. Odniesienia do nich mają na celu podkreślenie tego, że niektóre zwroty językowe, metafory oraz sposoby tłumaczenia, czym jest CCP oraz jak należy się jej uczyć, są podobne do tych używanych przez respondentów w ich potocznym języku. Podobieństwa te dowodzą, że zasób słowny opisujący CCP i do- świadczenia zmysłowe terapeuty manualnego jest ograniczony.

\section{Wiedza niedyskursywna i czucie ciała pacjenta: pomiędzy naukami społecznymi i medycznymi}

Najczęstsze ujęcie wiedzy zakłada, że wiedza to coś, co można werbalnie, językowo, symbolicznie przekazywać, co jednostki mogą uzgadniać między sobą. Wiedzę taką można określić jako wiedzę dyskursywną. Należy zadać pytanie, czy to jest jedyny rodzaj tego, co możemy określić mianem wiedzy. Czy mamy do czynienia z wiedza, która nie jest możliwa do zwerbalizowania lub jest w ograniczonym zakresie przekładalna na język? Czy wiedza może być zakorzeniona w ciele, poprzez wielokrotnie powtarzalne praktyki? Na to pytanie odpowiada twierdząco Michael Polanyi, zaznaczając, że „więcej wiemy, niż jesteśmy w stanie powiedzieć” (Polanyi 1966: 4 [tłum. własne]; Jakubowska 2015: 173174; 2017: 10-11). Ten rodzaj wiedzy jest określany mianem wiedzy niedyskursywnej. Rozróżnienie wiedzy dyskursywnej od niedyskursywnej często odnosi się do podziału na „wiedzę że” (know that) $\mathrm{i}$ „,wiedzę jak” (know how). Tę pierwszą możemy uzasadnić w sposób teoretyczny, jest komunikowalna, można ją przekazywać poprzez podręczniki, staje się zasobem wiedzy wspólnej. Natomiast „wiedzę jak” trudno uzasadnić w sposób teoretyczny, jest przekazywana poprzez praktykę, nie przyswaja się jej przez podręczniki, ale doświadczenie cielesne. Przykładowo, można zaliczyć do niej rzemiosło, gotowanie, pewne elementy umiejętności sportowych (np. czucie wody, czucie kortu, czucie piłki, czucie

\footnotetext{
${ }^{1}$ Część prezentowanego artykułu jest zmodyfikowaną wersją fragmentów mojej niepublikowanej pracy licencjackiej zatytułowanej "Myśleć ręka". Kompetencja czucia ciała w zawodzie terapeuty manualnego, obronionej na Akademii Wychowania Fizycznego im. E. Piaseckiego w Poznaniu.
} 
ciała przeciwnika w judo, pamięć mięśniową). Używa się również innych pojęć służących do opisu wiedzy niedyskursywnej. Mają one podobny sens, ale jednocześnie bardziej akcentują poszczególne jej cechy. Należy do nich kategoria „wiedzy milczącej” (tacit knowledge) (Polanyi 1966), która podkreśla to, że część naszej wiedzy nie ma charakteru językowego. Po prostu wiemy, jak coś zrobić, ale nie wiemy, jak to wyjaśnić („,coś robi się samo”). Przykładowo, wiemy, jak jeździć na rowerze, ale niezwykle trudno wytłumaczyć tę czynność krok po kroku dziecku, które się tego uczy. Wiedzę niedyskursywną też często utożsamia się z kategorią wiedzy zależnej od kontekstu (Jakubowska 2017: 16-17). Jeżeli trener krzyknie: „Mocniej rzuć tę piłkę”, „To był dobry rzut”, „Wybijaj się energiczniej”, to określony komunikat stanie się zrozumiały tylko i wyłącznie poprzez odniesienie tego do ruchu wykonywanego w danym momencie oraz przestrzeni. Komunikat oderwany od tego kontekstu będzie całkowicie niezrozumiały. Ten ostatni przykład uzmysławia nam dodatkowy ważny aspekt wiedzy milczącej. Jest ona często połączona $\mathrm{z}$ językiem werbalnym i dopiero wraz z nim staje się zrozumiała. W pewnych sytuacjach jedno bez drugiego nie ma racji bytu. Dana czynność wraz z komunikatem staje się czymś, co jest zrozumiałe dla uczestników określonej interakcji. Samo zachowanie bez dodatków słownych, nawet krótkich („wyżej”, „,mocniej”), oraz same słowa bez zachowania stają się trudne do zdekodowania. Inne pokrewne kategorie podkreślają znacznie zmysłów w procesie nabywania wiedzy. Należą do nich pojęcie wiedzy kinestetycznej, sensorycznej lub multisensorycznej. Rola poszczególnych zmysłów $\mathrm{w}$ procesie przyswajania wiedzy potwierdza to, że często coś wiemy, bo czujemy. Jest to inny rodzaj rozumienia niż rozumowe i językowe przyswojenie. Innym pojęciem, które warto wyróżnić, jest wiedza ucieleśniona. Dzięki tej kategorii podkreśla się, że jest ona przyswajana, ale też pokazywana innym poprzez ciało (Kaufmann 2004). Oddaje to dobrze stwierdzenie "fach w ręku”. Warto wyróżnić również pojęcie wiedzy motorycznej, czyli nabywanej poprzez ruch, oraz wiedzy praktycznej, nabywanej dzięki powtarzaniu czynności.

Współczesne zainteresowanie pojęciem wiedzy milczącej jest związane z materialistycznym podejściem do ciała wśród części przedstawicieli nauk społecznych. Jest to perspektywa, która dostrzega jego biologiczny, organiczny i "mięsny" wymiar (Bukraba-Rylska 2017: 189-208)². Odróżniana jest ona od podejść z nurtu idealistyczego, interpretatywnego i tekstualnego, które skupiają się na aspekcie symbolicznego nasycania ciała znaczeniami. Ciało w takim ujęciu staje się tworem kulturowym, ideowym. Taki zwrot ku biologicznemu ujęciu ciała daje szansę na szukanie pomostów między naukami społecznymi i biologicznymi, medycznymi. Zabieg taki nie może odbyć się bez prób translacji, czyli przekładania perspektyw tych różnych światów naukowych. Przykładowo, przedstawiciel świata nauk przyrodniczych mógłby zastanawiać się, o czym dokładanie rozmawiamy, mówiąc o wiedzy niedyskursywnej. Jakie procesy cielesne są powiązane $\mathrm{z}$ tym zagadnieniem. Z punktu widzenia fizjologii kategoria wiedzy niedyskursywnej i jej pojęcia pokrewne odnoszą się do (Paterson 2009: 766-788; Bringley 2012: 90):

- Zmysłu dotyku w postaci receptorów skórnych (eksteroreceptorów), na które składają się nocyceptory, odbierające wrażenia bólu, i mechanoreceptory, odbierające wrażenia do-

\footnotetext{
${ }^{2}$ Zapewne paradygmatów ujęcia ciała można byłoby wyróżnić więcej. Przedstawienie tego aspektu nie jest jednak celem prezentowanego artykułu. Wspominam tylko o tych dwóch podejściach w celu ukazania wyraźnego kontrastu, pokazującego potencjał pojęcia niedyskursywności.
} 
tyku i ucisku, oraz termoreceptory, odpowiadające za przetwarzanie bodźców termicznych, ciepła i zimna. Wśród narządów czucia można dodatkowo wyróżnić narządy czucia powierzchownego znajdującego się w skórze, a w największej liczbie na opuszkach palców, języku, podeszwach stóp. Pozwalają one na odbiór między innymi wrażeń termicznych, nacisku, swędzenia. W naszym ciele występują również narządy czucia głębokiego umiejscowione w mięśniach, więzadłach, ścięgnach, które przekazują informacje o stanach zapalnych, ciężarze, kształcie, twardości dotykanych powierzchni, przedmiotów.

- Propriocepcji, czyli zmysłu, który za pomocą proprioreceptorów znajdujących się $\mathrm{w}$ ścięgnach i mięśniach pozwala na czucie położenia części własnego ciała wobec siebie, koordynację mięśni, utrzymanie ich odpowiedniego napięcia względem siebie, i co za tym idzie - odpowiedniej postawy ciała.

- Kinestezji, która jest wiązana z czuciem i percepcją ruchu własnego ciała.

- Zmysłu równowagi - błędnika odpowiadającego za utrzymanie równowagi, odbieranie informacji związanych $\mathrm{z}$ oddziaływaniem siły grawitacji na ciało.

Zaprezentowany powyżej podział na dyskursywność i niedyskursywność należy traktować jako analityczną typologię. W rzeczywistości te dwa pojęcia tworzą kontinuum, na którym znajduje się wiele pośrednich przypadków. Niektóre czynności mogą być w mniejszym lub większym zakresie przekładalne na teoretyczne objaśnienie. Taki scenariusz ma miejsce $\mathrm{w}$ przypadku podręczników akademickich, w których tłumaczone są ćwiczenia wraz z rysunkami i wykresami (zob. np. Gąsior 2015). Niemniej jednak możliwość odczytania takich instrukcji jest zarezerwowana dla osób posiadających wiedzę ekspercką ${ }^{3}$.

\section{Na czym polega czucie ciała pacjenta?}

Zawód terapeuty manualnego jest ciekawym obszarem do badania społecznego wytwarzania i przekazywania wiedzy niedyskursywnej. Jego specyfika polega na tym, że w głównej mierze opiera się na wiedzy milczącej. Obszarami niedyskursywności w zawodzie terapeuty manualnego są: czytanie niewerbalnego języka ciała pacjenta oraz ocena jego zdrowia poprzez wzrok (postawa ciała, dostrzeganie, czy dotyk wywołuje dyskomfort, obserwowanie zmian wizualnych w tkankach podczas terapii), nauczanie pacjenta ćwiczeń korekcyjnych, umiejętność tłumaczenia schorzeń pacjentowi, czyli przekładanie diagnozy medycznej na zrozumiały język codzienny (na przykład użycie metafor). Zagadnienia te są poruszane $\mathrm{w}$ innych kontekstach przez badaczy społecznych, eksplorujących takie zagadnienia jak przekazywanie wiedzy w sporcie (Jakubowska 2017), uczenie się rzemiosła (Sennett 2010). Elementem, który może wprowadzić coś nowego do społecznej refleksji na temat wiedzy niedyskursywnej, jest CCP, obejmujące diagnozowanie oraz leczenie poprzez techniki manualne. Tematyka czucia ciała pacjenta odnosi się przede wszystkim do

\footnotetext{
${ }^{3}$ Granice między wiedzą dyskursywną i niedyskursywną są zmienne i historyczne. To, co obecnie wiemy, ale nie potrafimy wyjaśnić, w przyszłości może być poddane badaniom naukowym, skwantyfikowane i w sposób zrozumiały przełożone na teorię. Przykładowo, Frederick Winslow Taylor, twórca metody naukowego zarządzania organizacją, prace rzemieślnicze rozłożył na pojedyncze ruchy i przydzielił je osobnym pracownikom, co rozwinęło technologię pracy taśmowej. Biomechanika jako nauka oraz takie narzędzia pomiarowe jak system motion capture są wykorzystywane do mierzenia subtelnych i niewidocznych dla oka wzorców ruchowych.
} 
kwestii badania palpacyjnego (wyczuwanie struktur cielesnych przez dotyk). Nie jest to oczywiście jedyny aspekt CCP. Oprócz palpacji należy do niego zaliczyć wykonywanie testów diagnostycznych oraz technik terapeutycznych (np. mobilizacje, manipulacje stawów). Palpacja w książce Leona Chaitowa oraz Sandy Fritz jest opisywana następująco:

Palpacja dostarcza informacji sensorycznej, którą mózg interpretuje jako: temperaturę, teksturę, wilgotność, elastyczność, napięcie tkankowe, grubość, kształt, drażliwość, ruch. By wykorzystać pełnię możliwości w tym zakresie, należy własne palce nauczyć czuć, myśleć, widzieć i wiedzieć. Niektórzy czują przez własne palce badające ciało pacjenta, inni widzą struktury znajdujące się pod opuszkami palców, przywołując do świadomości obrazy zarejestrowane podczas anatomii, jeszcze inni myślą, które odczucia są normalne, a które nie, lub dzięki doświadczeniu nabytemu w długotrwałej praktyce wiedzą, że odczucia są rzeczywiste i właściwe. (2007: 80)

Atlas anatomii palpacyjnej Przewodnik po ścieżkach ciała rozpoczyna się przedmową, której fragment warto zacytować, ponieważ dobrze opisuje naturę nauki palpacji i jej niedyskursywności.

Znane jest powiedzenie Konfucjusza, który wieki temu przedstawił klucz do zdobywania wiedzy: „Powiedz mi, a zapomnę. Pokaż mi, a zapamiętam. Pozwól mi zrobić, a zrozumiem". Anatomia palpacyjna jest najlepszym sposobem poznania budowy ciała człowieka. To metoda uczenia się, która angażuje wszystkie zmysły, pozwala w dosłowny sposób „zrobić", czyli dotknąć - żeby zrozumieć. Autor znalazł sposób na uruchomienie naszej wyobraźni, co, jak wiadomo, pozwala naszej pamięci lepiej zakodować i potem odtworzyć poznane wiadomości. (Schleip 2018)
Badanie dotyczące czucia ciała pacjenta w zawodzie fizjoterapeuty różni się od większości badań dotyczących niedyskursywności tym, że nie chodzi w nim o czucie własnego ciała (uczenie się ćwiczenia sportowego), ale ciała kogoś innego (pacjenta). Dodatkowo w tym kontekście badamy nie relację własnego ciała z przedmiotami (rzemiosło i narzędzia pracy, pewne sporty, takie jak szermierka) lub żywiołami (czucie wody, czucie kortu), ale relację ciała z innym ciałem. Można zastanowić się, w jakich innych kontekstach można badać wiedzę milczącą w kontekście dotyk ciało-ciało. Należałby do nich kontakt intymny (seks, przytulanie się, przekazywanie sobie informacji poprzez dotyk między partnerami), głaskanie i masowanie zwierząt, rywalizacja sportowa (sporty walki, w szczególności takie jak judo, ju-jitsu, zapasy), kooperacja poprzez dotyk (taniec), diagnoza (odsłuch, badanie brzucha), terapia (praca lekarza, pielęgniarki). Praca terapeuty manualnego przynależy do tego ostatniego kontekstu i stanowi jego sprofesjonalizowaną formę, odróżniającą go od terapii dotykowych, które nie są oparte na nauce (znachorzy, medycyna alternatywna).

\section{Jak możemy rozumieć wysokie kompetencje w zakresie czucia ciała pacjenta?}

Respondenci zaznaczali, że CCP powiązane jest z dostrzeganiem następujących właściwości ciała: temperatury, ukrwienia, którą oddaje barwa skóry; obrzęków oraz jędrności.

Jak najbardziej, dlatego że rzeczywiście bardzo często, na przykład jeśli chodzi o pacjentów, o także pacjentki, to występuje choćby nawet róża limfatyczna, czyli no tkanka jest wtedy bardziej ścieńczona, ucieplona, więc myślę, że dotyk, dotykiem, 
tę temperaturę ciała każdy z nas, nawet jeśli nie jest fizjoterapeutą, to odczuwa. Więc tutaj nie trzeba nawet jakichś wielkich, wielkich doświadczeń fizjoterapeutycznych, żeby odróżnić różne rzeczy. Bardzo często ma trochę inny kolor, odróżnia się ta tkanka. Jest mniej taka jędrna, mniej ukrwiona, nie wiem, to są pola często jakieś, jakieś właśnie bardziej blade, czyli mniej właśnie takie, jak powiedziałam, ukrwione. Tak że to też widać. No i też czuć. Wielu pacjentów, których ja mam, jestem na specjalnych projektach przeciwobrzękowych, no i choćby nawet wizualnie widać po prostu, że tam ta limfa wylewa się do tkanek okalających, do przestrzeni śródtkankowej. No i wprowadzanie tego też nie jest gdzieś tam proste. I to widać. Widać. I no w praktyce też czuć. To nawet właśnie, może to czasami trudniej to wyjaśnić, mówiąc komuś [...]. (TM2)

Najważniejszym elementem CCP jest umiejętność rozróżnienia zdrowej tkanki od chorej. Należy zastanowić się, na czym polega odczucie patologii w tkance. Do jej opisu używa się różnych pojęć, które można zredukować do pojęcia "restrykcji”, "bariery”, „oporu”, który stawia tkanka dotykającemu fizjoterapeucie. Jedną z ważnych kompetencji w tym kontekście byłoby dostrzeganie różnicy między stanem sprzed i stanem po terapii. Innymi słowy, dostrzeganie zmian w tkance, czyli znikających „restrykcji”, „barier”.

[...] tkanka nowotworowa jest bardziej odporna, jest trochę, no ze względu nawet na tą swoją mutację, po prostu, zupełnie inaczej się wyrażająca. I w takiej najprostszej charakterystyce to można powiedzieć, że ona jest taka właśnie bardziej, bardziej zbita, bardziej solidna, bardziej jasna w dotyku. (TM2)

Zatem tkanka zdrowa, „normalna” nie stawia oporu. W takiej sytuacji dającą się zobiektywizować oceną byłby zero-jedynkowy werdykt istnienia oporu tkanki lub jego braku. Natomiast określenie jego wielkości stanowi subiektywne odczucie fizjoterapeuty.

Palpację wykonuje się poprzez przesuwanie własnych palców, ślizgając tkankę pacjenta w płaszczyźnie poziomej lub naciskając ją w płaszczyźnie pionowej. W tym drugim przypadku chodzi o siłę nacisku. Praktycznie wszyscy rozmówcy, którzy wspominali o tym aspekcie, zaznaczali, że „mniejsza siła" nacisku dostarcza większej liczby informacji i jest wskaźnikiem lepszej palpacji.

[...] jeżeli zbyt agresywnie zaatakuję mięsień, to on mi nie odpowie prawidłową sprężystością, taką, jaką ma w rzeczywistości, tylko patologicznie wejdzie $w$ napięcie $i$ wtedy ta moja praca będzie nieefektywna. (O8)

Zatem palpując, nie powinniśmy wytwarzać zbyt silnych stresorów wobec tkanek. Osteopatka wskazuje, że symbolizuje to „podążanie za tkanką".

Ja się nie skupiam na danych technikach, jakie wykonuję. Mnie po prostu prowadzi ciało pacjenta. Nie wiem, w jaki sposób mam ci to wytłumaczyć. (O7)

Z powyższego cytatu można wyciągnąć dwa wnioski. Po pierwsze, terapeuta, naciskając na tkankę, powinien być przez nią „prowadzony”, tak jak ktoś prowadzi nas za rękę. Innymi słowy, nacisk nie powinien wymuszać ruchomości tkanki w określonym kierunku, tylko powinien opierać się na takiej sile, która zachowa jej naturalną ruchomość. Po drugie, jest to element palpacji, który "trudno wytłumaczyć", co wskazuje wprost na typowy problem z przełożeniem wiedzy niedyskursywnej na płaszczyznę języka werbalnego. Użycie małej siły nie 
oznacza, że nie jesteśmy w stanie wyczuć tego, co znajduje się w głębokich warstwach ciała pacjenta. Zdaniem terapeutki manualnej dobra palpacja jest zarazem delikatna, ale również „głęboka”.

Osoby, które mają bardzo dobrą palpację, można ich palpację poznać po tym, że wcale nie jest silna, jeśli chodzi o aplikowany nacisk, a zarazem jest głęboka, ponieważ dociera do głębi leżących struktur. I jeśli się jest pacjentem, to bardzo łatwo można wyczuć różnicę pomiędzy docieraniem $\mathrm{w}$ głąb, a naciskaniem mocno. (TM3)

Jak małej siły powinniśmy użyć, trudno wyjaśnić poprzez słowo „mała”, ponieważ to subiektywna kategoria. Zamiast tego można posłużyć się obrazowym przykładem.

Jak pana prowadzącego kurs zapytano, jaka siła właśnie powinna być użyta do tej zwłaszcza palpacji czy technik tam, powiedzmy, terapeutycznych w stopniu pierwszym, to on powiedziałby, że tak, że gdyby pomiędzy palcem a ciałem terapeuty znalazła się mucha, to jej się nie powinny ugiąć kolana. (TM1)

Oprócz nieinwazyjności i głębokości palpacja powinna być „czuła”. Mistrzami jej są ci, którzy potrafią wyczuć subtelne i małe szczegóły w ciele pacjenta.

W czym jest większa trudność. Tak. No dużo rzeczy dla mnie jeszcze stanowi wyzwanie. Generalnie rzecz biorąc, no są, są struktury, no im mniejsza struktura, tym jasne, że będzie trudniej wyczuć. Więc bierzmy na to na przykład trzustkę, która jest głęboko, daleko. Ją wyczuć dobrze, no to już naprawdę jest rzecz szalenie trudna. Przysadka mózgowa. Mówię teraz o teoretycznie abstrakcyjnych rzeczach, ale potencjalnie da się to, da się to wyczuć. (O9)
R: [...] czy sprawdzałeś, zamykałeś oczy i sprawdzałeś strukturę zwykłej tkanki a tkanki z tatuażem?

B: Nie.

R: To sobie to sprawdź. I ja mam takie czucie, że właśnie jestem ci w stanie dokładnie określić, gdzie ten tatuaż przebiega. W sensie, w którym miejscu się kończy.

B: Aha, gdy masz zamknięte oczy.

R: Gdy mam zamknięte oczy. (TM5)

Podczas wywiadów w szczególności osteopaci wyróżniali własne podejście jako to bazujące na dużej wrażliwości w CCP. Zaznaczano, że standardowe "czucie fizjoterapeutyczne" to czucie konkretnego miejsca w ciele lub struktury. "Czucie osteopatyczne" to zdolność do czucia całego ciała pacjenta. Dodawano również, że czucie osteopatyczne jest ukierunkowane na bardziej subtelne rzeczy i szczegóły, które często umykają szeregowym fizjoterapeutom.

To, czym w dużej mierze różni się osteopatia od fizjoterapii, jest właśnie [śmiech] ta wrażliwość na te subtelne rzeczy. Bo to, co interesuje osteopatę, to fizjoterapeuta może gdzieś tam czasami ominąć, bo nie był po prostu tego nauczony wcześniej, bo skupiał się na dużych rzeczach, pod tytułem zablokowany staw, napięty mięsień właśnie, oczywiście, ja to upraszczam bardzo mocno. Ale to właśnie o to nam chodzi, że osteopata będzie skupiał się często na takich super subtelnych rzeczach, które normalnie by umknęły. I dlatego skuteczność też jest w wielu przypadkach wyższa osteopatii, tylko że osteopatii nie należy do końca porównywać do fizjoterapii, bo to są dwie różne dziedziny. (O9)

Zatem palpacja powinna być delikatna, głęboka i czuła. Wszystkie te trzy cechy są ćwiczone poprzez praktykę i edukację na studiach oraz kursach. Brak tych zdolności w szczególności widać wśród 
studentów fizjoterapii, którzy dopiero rozpoczynają naukę CCP.

Wiesz co, jeżeli chodzi o palpację, to tak zauważyłem, tak jak ci mówiłem, że na ogół ci, którzy byli spokojniejsi, delikatniejsi [...] byli wyciszeni emocjonalnie na samym początku, czyli, wiesz, nie ładowali się gdzieś tam palcami, głęboko szukali na siłę, to bardzo często gdzieś tam początkowo odnosili lepsze rezultaty, niż ci, którzy, wiesz, na chama gdzieś tam próbowali coś znaleźć. (O10)

\section{Metafora jako podstawowe narzędzie językowe transmisji czucia ciała pacjenta}

Wiedząc, czym jest CCP, należy zadać sobie pytanie, jak jest ono przekazywane. Intersubiektywizacja CCP kończy się w momencie, kiedy pojawia się wspólnota czucia, czyli doświadczania podobnych wrażeń i ich adekwatnego rozpoznawania. Pierwszym krokiem, aby doszło do takiej sytuacji, jest wstępne wyobrażenie sobie, co dokładnie należy poczuć. Dopiero w dalszej kolejności ćwiczy się kompetencje, które mają to umożliwić. Ten pierwszy krok często jest pokonywany przy użyciu metafor. Metafora wydaje się być najlepszym instrumentem językowym tłumaczącym specyfikę tego, co się czuje, ponieważ z zasady tłumaczy to, co nieznane poprzez to, co znane, pozwalając uruchomić wyobraźnię i szukać podobnych doświadczeń w innych, bardziej uniwersalnych obszarach. Metaforami posługują się zarówno autorzy podręczników, jak i respondenci. Można je uznać za podstawowe i uniwersalne narzędzie językowe (używane w różnych kontekstach przekazywania wiedzy takich jak podręczniki, zajęcia praktyczne, wywiady) tłumaczenia wrażeń, które odczuwa się podczas palpacji. W taki sposób czucie pewnych struktur tłumaczy na przykład Stephen Typaldos. Ksiażka Typaldosa wyróż- nia się tym, że podaje się w niej barwne i oryginalne porównania i metafory, opisujące doznania dotyku patologicznej tkanki. Oto kilka przykładowych metafor: "gąbczasty marmur"; ,"uczucie topnienia”, gdy tkanka wychodzi ze stanu patologicznego; „kolumna kręgosłupa” jako „stos monet”, podskórna pomarszczona tkanka jako „fala”, deformacje powięzi jako „soczewica”, „skręcona wstążka”, "rant taśmy”, „węzeł”, "gotowany groszek”, ,ziarno soli”, „migdał”, „,krawędź gumki od ołówka” (Typaldos 2002: 27, 28, 127, 265, 267 [tłum. własne]). Natomiast Andriew Biel porównuje strukturę powięzi do „wnętrza pomarańczy”, a powierzchnię mięśni poprzecznie prążkowanych do „nieoszlifowanej deski” (Biel 2018: 11). Wywiady z terapeutami manualnymi dostarczają innych obrazowych metafor: densyfikacje jako sklejenia powięziowe; punkt spustowy jako „ziarenko grochu”, „piasku”, „koralik”; deformacje powięziowe jako „końcówka wkładu do długopisu”; inne patologie jako "gąbczasta kuleczka"; napięte włókna mięśniowe jako „nitki” lub „struny”.

R: [...] tak sobie można to wizualizować [...] bombka jest dobrą analogia.

B: Jako głowa, czaszka?

R: To jest, tak. To można tak sobie to wyobrazić, że to jest tak delikatne, że jeśli zbyt mocno, to bombka pęknie. (TM1)

No jeżeli mamy napięty, napięty pęczek włókien mięśniowych, no to ktoś powie, że jest to sznureczek jakiś albo struna, którą można brzdękać, na przykład, w jakimś tam środowisku, które ma inną właśnie konsystencję. I tu jest nagle coś, co brzdęka. Albo troczki, na przykład, rzepki czy troczki, w okolicy stawu skokowego, ze względu na taką bardziej prążkowaną strukturę tej tkanki łącznej, też chrupią troszkę pod palcami. Można pstrykać, jakbyśmy po tkaninie prążkowanej przejeżdżali i to akurat wdzięcznie poddaje 
się takim opisom jakimś naśladującym jakieś inne zjawiska czy dźwięki. To też tak się mówi. I to ułatwia wyszukiwanie. (TM3)

Myślę, że takie metafory są przydatne, bo one ułatwiają wyobrażenie sobie tej struktury. Bo jeżeli mówimy o punkcie spustowym, to on nigdy nie dotyczy stu procent włókien danego mięśnia, tylko właśnie jakiegoś tam odsetka dotyczy. Więc to może być taka grudeczka. To może być to ziarenko piasku. Dlatego to powinno uzmysłowić, chociażby osobie uczącej się, w jaki sposób powinna dokonywać tej palpacji. Jeżeli ona chce rzeczywiście znaleźć to ziarenko piasku albo tą grudeczkę, no to nie może tej dłoni przykładać co pięć centymetrów i szukać tej grudeczki, a niektórzy w ten sposób tak to robią, odrywając ją. Jeżeli szukam tego ziarenka piasku, no to muszę przesuwać dosłownie o milimetry [...], żeby to miejsce znaleźć. To może po prostu pomagać $\mathrm{w}$ uzmysłowieniu, wyobrażaniu sobie, tego, co robię. Szukam tego ziarenka, tego włókienka, które właśnie jest bolesne, które nie pozwala temu mięśniowi się dokładnie rozluźnić. (TM4)

Przedstawiane metafory służące do opisu doświadczeń dotykowych są przykładem zbiorowego radzenia sobie $\mathrm{z}$ barierami w przekazywaniu wiedzy niedyskursywnej przez terapeutów manualnych. Bariery te są wspólne tej grupie zawodowej od początku jej istnienia. Zbiór słów, porównań i metafor, których używa się do opisu CCP, należy traktować jako językowy rezultat wielopokoleniowych zmagań z barierami w intersubiektywizacji CCP. Można uznać, że ta grupa zawodowa radzi sobie z tym bardzo dobrze, ponieważ dzięki odwołaniom do uniwersalnych doświadczeń dotykowych (ziarenko piasku), nawet laicy mogą wyobrazić sobie (ale nie poczuć), na czym polega specyfika tkanki o nieprawidłowej konsystencji.

\section{Proces nabywania wiedzy dotyczącej czucia ciała pacjenta}

Jednym ze sposobów nauki CCP jest czytanie książek, które opisują jego specyfikę oraz dają wskazówki, jak je rozwijać. Książki dotyczące anatomii palpacyjnej są wzbogacone ilustracjami, rysunkami oraz zdjęciami (np. Tixa 2008). Pokazywane są na nich struktury, warstwy ciała oraz przyłożone do nich dłonie, co ma pozwolić czytelnikowi wyobrazić sobie czynność palpacji. Oprócz tego pojawiają się w nich praktyczne porady. Przykładowo, Biel zaznacza, że najlepszą metodą nauki palpacji jest bezpośrednie sprawdzanie tego, co się „przeczytało", na własnym ciele lub ciele kogoś innego. Dodatkowo warto stosować delikatny dotyk, utrzymywać spokojny oddech, wizualizować dotykany punkt, werbalizować własne odczucia na głos. Palpacja, zdaniem Andriew Biela, opiera się na trzech podstawowych zasadach (2018: 8).

Poruszaj się powoli. Pośpiech zakłóca czucie.

Unikaj używania nadmiernie silnego nacisku. Im mniej, tym naprawdę lepiej.

Skup się na swoich odczuciach z dłoni. Innymi słowy, bądź obecny.

Można streścić te zasady do następujących haseł: powoli, delikatnie, uważnie. Oprócz takich praktycznych porad Biel sięga ponownie po metaforyczny język. „Zamiast naciskać na mięśnie i inne tkanki, spróbuj «zaprosić» tkanki, żeby to one znalazły twoje dłonie" (Biel 2018: 5).

W pewnym zakresie CCP jest przekazywane i możliwe do wytłumaczenia za pomocą dyskursywnych form wiedzy, takich jak książki. Na pewno bogaty materiał ilustracyjny oraz metafory, poprzez które próbuje się porównać pewne 
powszechne doznania dotykowe (np. groszek) do dotykanej struktury, są użyteczne. Przyszły praktykant może przed przystąieniem do pierwszych prób palpacji wstępnie wyobrazić sobie doznania zmysłowe oraz „widzieć” struktury, które znajdują się pod powierzchnią skóry. Niemniej jednak niedyskursywny charakter CCP sprawia, że te konwencjonalne formy przekazywania wiedzy posiadają duże ograniczenia i nie mogą stanowić głównego filaru procesu edukacji.

Co może oznaczać „dotykaj delikatne”? To określenie można rozumieć w różny sposób. Sprawia to, że najważniejsza $\mathrm{w}$ tym przypadku jest praktyka oraz bezpośredni kontakt między nauczycielem i uczniem, pozwalający na wymianę własnych doświadczeń na bieżąco. Taka forma edukacji ma miejsce na studiach fizjoterapeutycznych na zajęciach, na których są ćwiczone techniki terapeutyczne, oraz przede wszystkim na różnego typu specjalistycznych szkoleniach. Respondenci podkreślali, że pomiędzy studentami są różnice w szybkości rozwijania kompetencji CCP. Tych, którzy nie posiadają odpowiednich predyspozycji, określali jako mających „drewniane” lub „ciężkie” ręce. W sposób biologiczny tłumaczyli to "gorszymi predyspozycjami genetycznymi” lub „mniejszą ilością zakończeń nerwowych" na opuszkach palców.

Podczas wywiadów pojawiły się głosy mówiące, że na studiach nie podkreśla się wystarczająco znaczenia CCP. Podobna sytuacja zdarza się również na szkoleniach.

[...] na pewno jest zaniedbana ta palpacja na studiach i w ogóle anatomia jest mocno zaniedbana na studiach. Nie mówię, że jest słaba, tylko uważam, że powinna być o wiele mocniej i lepiej prowadzona, powinni mieć dużo więcej zajęć, przynajmniej w przypadku fizjoterapeutów, tak samo fizjologia. Ale głównie ta anatomia jest tak mocno, no uważam, że powinni mieć dużo, dużo więcej zajęć. Żeby pewne rzeczy gdzieś tam zrealizować, bo tak naprawdę to jest no, to jest człon, na którym się opiera, wiesz, cała reszta. (O10)

Akurat na szkoleniach nie zawsze się na to, mam wrażenie, zwraca do końca uwagę. Chyba, że ktoś zada tego typu pytanie. I wtedy się wywiązuje dyskusja. Ale na tych kursach, na których bywałam, to niekoniecznie zwracano aż tak mocno na to uwagę. Po prostu było badaj, sprawdzaj, na tej zasadzie. Nie czujesz, rób jeszcze raz. Zrób to jeszcze raz. Spróbuj jeszcze raz. Porównaj ze zdrową kończyną, jeżeli nie jesteś pewna. Na tej zasadzie. (TM4)

Ten brak najprawdopodobniej wynika z niedyskursywności CCP, która tworzy liczne bariery w jej nauczaniu. Powodem tego jest również założenie, że nie ma lepszego sposobu na nauczanie się CCP niż praktyka i ćwiczenia.

Transmisja CCP, podobnie jak wielu innych umiejętności związanych z wiedzą niedyskursywną, jest spowolniona, nie odbywa się w momencie pokazu, tłumaczenia, szkolenia. Oznacza to, że fizjoterapeuta biorący udział w szkoleniu może nawet po kilku latach zrozumieć, o co dokładnie chodzi w danej technice. Wówczas zaczyna się czuć początkowo abstrakcyjnie brzmiące słowa.

Ja generalnie zjazdy osteopatyczne w czasie nauki zazwyczaj pojmowałem tak dwa lata po nim. Musiałem dwa lata pracować dopiero technikami i tym, co się tam nauczyłem, a i tak jeszcze wielu, wielu rzeczy nie rozumiem. Albo myślę, że jeszcze jest bardzo daleka droga do tego, żeby to wszystko zrozumieć, zastanawiam się, czy życia starczy. (O1) 
I z tego też tytułu wielu terapeutów po kursie albo w trakcie kursu jest sfrustrowanych, że instruktor pokazując im jakąś tam technikę, nie mają tego odczucia, jakie powinni poczuć, że on im relacjonuje, jakie wrażenie powinni mieć, a oni tego nie czują. I to niestety, żeby to złapać, to czucie takie tkanki czy czucie dysfunkcji, to wymagana generalnie jest praktyka. Tego bez praktyki się nie uda wykonać. Trzeba mieć oczywiście wiedzę. Ale trzeba ileś tam tych pacjentów przerobić w życiu [...]. I ja to oceniam teraz po latach, że jak nawet pokazuję komuś technikę i kogoś uczę tej techniki, to ta technika dla mnie jest po prostu prosta, prawie że intuicyjna i ja te napięcia czuję. Ktoś później po mnie chwyta tego pacjenta i mówi, że „kurka, zupełnie nie potrafię tak zrobić, zupełnie tego nie czuję". (O8)

W przypadku CCP potrzeba czasu włożonego w przyswojenie określonej wiedzy poprzez jej ucieleśnienie. Dopiero w momencie, gdy zarówno na poziomie "głowy" (układu nerwowego) zrozumiemy i ciała (układu mięśniowo-powięziowego) poczujemy, dokonuje się transmisja wiedzy. Przyswajanie i ucieleśnianie wiedzy jest procesem ciągłym. Terapeuci manualni twierdzili, że zawsze jest coś nowego do nauczenia się i każdy przepracowany dzień stanowi kolejny mały krok ku mistrzostwu w czuciu ciała pacjenta.

[Na początku mojej pracy zdarzało się to - przyp. AM] co pacjenta: eureka, eureka, eureka, eureka. Kurde, masakra. Ja to czuję. To jest niesamowite. [...] to się dzieje cały czas później, tylko że to są bardzo drobne rzeczy. To trzeba właśnie umieć zwrócić na to uwagę, nie wiem, wpakować ręce w środek brzucha i powiedzieć „czuję mięsień biodrowo-lędźwiowy, no wow, bo jest taki, no jak, jak go nie wyczuć, nie?" Tylko chodzi o to, żeby poczuć, gdzie on jest napięty i czy rzeczywiście ja muszę rozluźniać ten mięsień, czy może wystarczy zrównoważyć jakieś napięcie. Wyczuć centrum tego. I teraz, to może, o czym pan nie wie, ale robi pan, robi pan badania na temat czucia... Dzięki rozwiniętemu czuciu myślę, że już na jakimś poziomie to czucie mam, jestem w stanie określić [...], gdzie dokładnie jest centrum tego napięcia, gdzie jest jakby taki spadek energetyczny wewnątrz, wewnątrz ciała pacjenta. (O1)

W tym kontekście kartezjański podział na ciało i umysł jest problematyczny, ponieważ przyswojenie wiedzy ma miejsce nie w momencie, gdy coś jest zapamiętane, ale gdy jest poczute na poziomie cielesnym i następnie manualnie zastosowane przy pomocy rąk - podstawowego instrumentu terapeuty (Mauss 2001: 201-211). Czasami wręcz nadmierne myślenie może zaburzać terapię.

Naprawdę nie umiem tego ubrać w słowa! [wyróżn. AM] Bo myślenie czasami nam trochę zaburza. Powinniśmy myśleć ręką [wyróżn. AM], ona czuje. To ona czuje i ona nam jakby mówi, co my mamy robić. Jak włączymy mózg do tego albo pacjent odezwie się, to jest jakby to zaburzone. (O7)

Respondenci podkreślali, że nauka i praca każdego terapeuty manualnego jest ciągłym oscylowaniem pomiędzy dyskursywnymi i niedyskursywnymi wymiarami wiedzy, pomiędzy wiedzą teoretyczną a ucieleśnioną praktyką terapeutyczną, pomiędzy tym, co przekazywane językowo a tym, co jest czute. Struktury anatomiczne ciała pacjentów muszą być zapamiętane (przykładowo przyczepy mięśnia). Wiedza taka jest jednak mało praktyczna z punktu widzenia zawodu terapeuty manualnego. Dopiero umiejętność wyszukania określonych struktur, czucia ich, manipulowania nimi pozwala na leczenie pacjenta. Ponadto wiedza anatomiczna przedstawiana w podręcznikach często ma się nijak do zróżnico- 
wania anatomicznego poszczególnych osób. Każdy pacjent wraz ze swoją charakterystyką (płeć, ilość tkanki tłuszczowej, typ budowy ciała) stawia określone wyzwania związane ze znalezieniem i manipulacją daną tkanką. Dlatego też terapeuci z czasem wyrabiają w sobie coś, co można nazwać wyobraźnią anatomiczną lub subiektywnym skanerem ciała. Wyobraźnia ta polega na umiejętności tworzenia obrazów mentalnych tego, co znajduje się pod skórą pacjenta i co się z tym dzieje. Takie kontekstualizowanie wiedzy anatomicznej do konkretnych przypadków można nazwać procesem budowania coraz pełniejszego obrazu żywego ciała pacjenta.

[...] to zupełnie inaczej wygląda. Mamy zupełnie inne wyobrażenie. Jak te mięśnie mogą mieć dwa milimetry na przykład. A na atlasie wygląda jakby to był gruby kawał mięśnia. [...] Na przykład te mięśnie wszystkie, które są z tyłu na plecach, to one są wszystkie są dosyć cienkie [wywiad terapeutka manualna]. (O7)

\section{Kilka praktycznych sposobów przekazywania CCP}

Jak było wspomniane, CCP nabywa się poprzez praktykę. Nie oznacza to jednak, że nie istnieją konkretne praktyczne metody jej nauczania. Niektóre z nich są uniwersalne i stosowane w różnych miejscach, w których znaczenia nabiera wiedza niedyskursywna (np. pokaz), a inne są specyficzne dla CCP. Po pierwsze, wykorzystywane są tradycyjne metody przekazywania wiedzy poprzez pokaz i jednoczesne tłumaczenie. Między innymi na szkoleniach prowadzący może prowadzić rękę uczącego się, pytając, czy ten czuje poszczególne struktury.

Więc na tym szkoleniu jak byłam i na przykład miałam problem z jakąś techniką, no to podchodził in- struktor, on to robił na tobie, żebyś mniej więcej mógł się zapoznać z tym, jak ty to odczuwasz, a później stawał za tobą i wykonywał ten ruch razem $\mathrm{z}$ tobą. I w ten sposób miałam w pamięci, jak jest, powiedzmy, jak on to zrobił, jak ta technika wyglądała. I później kilkakrotnie po prostu cały czas starałam się osiągnąć ten sam stopień, powiedzmy, trakcji czy danej techniki. (TM5)

Po drugie, korzysta się z różnego typu metod pośrednich. Bezpośrednie rozwijanie CCP odbywa się poprzez dotyk innych ludzi. Można to robić również w sposób pośredni przy użyciu przedmiotów i substancji, do których można zaliczyć między innymi ćwiczenia delikatności dotyku poprzez ściskanie balonu, wyczuwanie bardzo małych przedmiotów poprzez poduszkę lub użycie mąki kukurydzianej.

Mogą być techniki pośrednie i bezpośrednie. Spotkałem się z czymś takim, że w technice na przykład pośredniej, tacy moi koledzy, którzy prowadzą kurs masażu tkanek głębokich, to oni chcą pokazać, w jaki sposób powinno się subtelnie wchodzić $\mathrm{w}$ mięsie [...]. I oni robią tak, że chyba w miskę z wodą wsypują mączkę kukurydzianą, która gęstnieje, i jeżeli się mocno zaatakuje tą ręką tą mączkę, to ona twardo reaguje, a jeżeli powoli, to, to ręka wchodzi. [...] Więc to jest taka trochę technika pokazująca, że w podejściu do tkanki trzeba być takim trochę subtelnym, powolnym, żeby to poczuć. (O8)

Po trzecie, palpację można ćwiczyć również na sobie. W odróżnieniu od pacjentów nasze ciało jest cały czas dostępne dla nas. Dotykając siebie, jednocześnie czujemy - mamy symultaniczny dostęp do dwóch perspektyw dotykającego i dotykanego. Można uznać, że pierwszym i najważniejszym pacjentem dla terapeuty manualnego jest on sam i po- 
znając dobrze własną anatomię, będzie mu łatwiej zrozumieć anatomię innych ludzi.

Po czwarte, kolejną możliwością rozwoju CCP jest czasowe zdystansowanie się względem innych zmysłów i skupianie się tylko na dotyku. Chodzi przede wszystkim o ograniczenie dopływu bodźców poprzez zamknięcie oczu, co pozwala się uważniej skupić na doświadczeniach haptycznych.

Myślę, że gdyby porozmawiać z doświadczonym praktykiem klasycznego masażu leczniczego, który dziś nie jest przecież traktowany jako jakaś nadzwyczajnie odkrywcza metoda lecznicza, to miałaby ta osoba również wysoko rozwiniętą wrażliwość palpacyjną, z której zwykle w tym środowisku słynne były osoby niewidome. [...] Tak zwykle się przyjmowało, że niewidomy masażysta to jest ten, który o wiele lepiej czuje, bo tylko tym się zajmuje, ma bardzo rozwiniętą tą wrażliwość, zapewne tak jest. (TM3)

Po piąte, kolejną metodą są techniki mentalne. Podczas palpacji potrzebna jest koncentracja i spokój. Te kompetencje można ćwiczyć poprzez medytację, wyciszenie się. Zalicza się do niech również metody wyobrażeniowe. To zagadnienie jest powiązane z wyobraźnią anatomiczną, która była opisywana wcześniej.

Po szóste, na poziom CCP może wpłynąć również uczestnictwo w sekcji zwłok i dotykanie struktur $\mathrm{w}$ rozciętych i nieżywych ciałach.

Po siódme, CCP ćwiczy się poprzez prace $\mathbf{z}$ innymi doświadczonymi fizjoterapeutami. Pojawiają się tutaj dwa warianty. Możemy wykonywać pewne techniki lub szukać określonych struktur na osobie, która wie, jakie odczucia powinno to wywoływać (na przykład instruktor lub pacjent, który wielokrotnie przechodził daną terapię). W trakcie ćwiczenia informuje ona nas, czy jesteśmy w odpowiednim miejscu i czy wykonujemy coś dobrze. Możemy również praktykować z osobą nas nauczającą. W pierwszej kolejności osoba nauczająca wykonuje określoną technikę, a następnie osoba ucząca naśladuje ją. Następnie osoba, na której robiono technikę, porównuje i mówi o różnicach w odczuciu pomiędzy modelowym a naśladującym wykonaniem.

Po ósme, CCP może być ćwiczone na nietypowych pacjentach, którzy nie mogą nam werbalnie - za pomoca języka - przekazać informacji zwrotnej, na przykład o tym, że terapia wywołuje dyskomfort. Do takich pacjentów należą niemowlęta oraz zwierzęta - głównie psy i koty.

Kiedyś na jednej z konferencji pan profesor [nazwisko] [...] zalecał ćwiczenia głaskania kota. [...] Ponieważ stwierdził, że to są zwierzęta, które są bardzo wrażliwe na dotyk. I nieprzyjemny dotyk, one po prostu no tego nie akceptują. One sobie po prostu pójdą w inne miejsce i nie pozwolą się głaskać, dotykać. W związku z czym właśnie twierdził, że ten dotyk, tą palpację właśnie ćwiczył na kocie. [...] Właśnie to do dzisiaj pamiętam. [...] Tak się mówi, że koty chodzą swoimi ścieżkami, że coś im się nie będzie podobało, to nie będą tego akceptować. (TM4)

[Wraz z kolegą - przyp. AM] leczyliśmy się jakby nawzajem, on się położył i tak spojrzał na mnie i mówi „proszę cię, lecz mnie jak psa” [śmiech obu osób]. (O7)

\section{Zapośredniczone przez przedmioty czucie ciała pacjenta}

Praca manualna najczęściej opiera się na bezpośrednim dotyku palcami terapeuty ciała pacjenta. Większość terapeutów wspominała, że pracuje tylko 
w ten sposób, ponieważ daje to bardziej wiarygodne i dokładne informacje, niż gdy dotyka się ciała pacjenta przy użyciu przedmiotu.

Próbowałem. Mam coś takiego. Faktycznie [...] mam takie drewienko, taki masażer do rozluźniania. I korzystałem z niego może łącznie dziesięć razy przez dobre siedem lat. $\mathrm{W}$ momencie kiedy rzeczywiście czuję, że jest ewidentne takie sklejenie po prostu, taka densyfikacja powięziowa, że właściwie tego densyfikacją to ciężko nazwać. To jest jak zwłóknienie, czyste zwłóknienie. No i żal ręki na to, żeby po prostu coś takiego robić. No muszę użyć siły, jak to musi być zwykła, brutalna siła, po to, żeby ją skupić $\mathrm{w}$ jak najmniejszym miejscu, no to tak, to czasem tego użyję. Natomiast używam tego wtedy przez jakieś piętnaście, dwadzieścia sekund i stwierdzam, że muszę wrócić do kciuka, bo to jest bez sensu. To jest bez sensu. Kierunek siły, sam dotyk punktu to jest jedno. Natomiast jeszcze kierunek tego dotyku, czy popycham to bardziej $w$ kierunku przednim, tylnym, z jaką siłą i z jaką rotacją, rotacja jest bardzo ważna, $\mathrm{w}$ prawo czy w lewo, jednak rotuję z tym uciskiem, to jest szalenie ważne. A to czuć ręką może i dałoby się przez to drewienko. Jak ktoś jest bardzo wprawiony, to może tak. Może tak. Ale na pewno dla mnie to zubaża ogromnie. (O1)

Pomimo takich argumentów, niektórzy terapeuci używają przedmiotów, ponieważ istnieje możliwość wyćwiczenia czucia poprzez nie. Przedmioty martwe moga przenosić część wrażeń, ale nie wszystkich. Wrażenia te w sposób zapośredniczony są odbierane przez dłonie terapeuty.

W pewnym momencie na przykład, i to tak być może jest w masażu tajskim, sam zaobserwowałem, że jak zastosowałem łokieć, to czucie w okolicy łokcia terapeuty również się poprawia. Czyli jesteśmy się w sta- nie nauczyć czuć łokciem. I tak samo być może część terapeutów stosujących jakieś narzędzia pomocnicze będzie czuła poprzez to narzędzie. [...] Poprzez przedmiot. Ciekawy byłby aspekt [...]. Czy może na przykład, trzymając drewniany patyk... [...] Czuć poprzez patyk, tak? (TM1)

W tym przypadku przedmioty stanowią podobne przedłużenie ciała jak proteza u osoby po amputacji kończyny. Jeden z respondentów wspominał, że z podobnym dylematem mierzą się lekarze, którzy tracą część własnych wrażeń sensorycznych podczas operacji chirurgicznych przy użyciu robotów. Warto jednak zaznaczyć, że pomimo utraty pewnych wrażeń, przedmioty stosuje się z powodu ergonomii i chęci oszczędzenia własnych palców, które w wyniku intensywnej eksploatacji mogą ulegać deformacjom i kontuzjom.

\section{Dylemat opozycji subiektywizm versus obiektywizm}

CCP nie zawsze dotyczy tylko i wyłącznie elementów czysto naukowych, co dla wielu czytelników oraz terapeutów niekoniecznie musi być łatwe do zaakceptowania. Te elementy jednak wydają się być nieusuwalne i wpisane $\mathrm{w}$ proces zamazywania granic między tym, co jest poddawane wyjaśnieniu a tym, co jest na nie oporne. Nieuchronnie prowadzi to do tego, że terapeuci stoją w obliczu problemów z pogranicza epistemologii i filozofii nauki. Dowodem tego jest dyskusja nad naturą CCP, jego stosowaniem i rozwijaniem, standardami skuteczności leczenia, która powoduje konieczność zmierzenia się z kwestią naukowości różnych szkół terapii manualnej, ustalenia linii demarkacyjnej między medycyną alternatywną a medycyną głównego nurtu. Wówczas pojawia się pytanie o granice tego, co można poczuć. Kiedy obiektywnie coś można wy- 
czuć, a kiedy pojawia się autosugestia? Problem ten w szczególności dotyczy technik, które stosują osteopaci, obejmujących manipulację przepływu płynu mózgowo-rdzeniowego pod czaszką i organów wewnętrznych.

Fizjoterapia i różne szkoły terapii manualnej opierają się na etosie naukowym. Podkreślając znaczenie tego aspektu, respondenci nieuchronnie wspominali również o roli wiary i intuicji. Mają one dwuznaczną rolę w pracy terapeuty manualnego. $\mathrm{Z}$ jednej strony brak wiary $\mathrm{w}$ możliwość wyczucia pewnych subtelnych procesów cielesnych może ograniczyć czyjąś skuteczność i rozwój zawodowy. Pozytywne podejście mentalne pozwala na podejmowanie ryzyka, dzięki któremu można szybciej uczyć się oraz przyczyniać się do innowacji i odkryć.

Ta technika sama się tworzy w trakcie tego, co my znajdziemy. Czasami ja coś robię kompletnie nielogicznego dla mnie, ale to samo mnie to jakby ciągnie i pacjentowi jest lepiej. [...] Jakby nie jestem jeszcze na takim poziomie, żeby wiedzieć to natychmiast. Czasami po prostu dochodzę do tego przez przypadek [wywiad terapeutka manualna]. (O7)

Z drugiej strony zbyt optymistyczne nastawienie, zbyt silna wiara $\mathrm{w}$ to, co się czuje pod palcami może doprowadzić do autosugestii i brnięcia w sferę pogranicza terapii opartej na nauce oraz efektu placebo, „szarlataństwa”, psychologicznej manipulacji pacjentem.

Pierwsza postawa zakłada, że mamy wierzyć w to, co czujemy, [...] właśnie dlatego powiedziałem, że to jest jak najbardziej subiektywne. A drugie podejście mówi, że my często czujemy to, w co wierzymy. (TM2)
Niektórzy rzeczywiście czują, niektórzy nie. Wiem, że były na przykład robione badania takie, w sumie nie wiem, czy dla żartu, że wzięto iluś tam osteopatów i kazali zbadać śledzionę na przykład. Ten mówił to, ten mówił to, ten mówił tamto. A za chwilę powiedzieli, że pacjent nie ma śledziony [wywiad terapeuta manualny]. (O7)

Dotykowe leczenie pacjenta dotyczy też naukowego uprawomocnienia, zobiektywizowania, skwantyfikowania tego, czym jest CCP. CCP jest podstawową kompetencją terapeuty manualnego. Terapeuci manualni działają w kontekście medycznym służby zdrowia. Ich działania łączy się z rehabilitacją lub leczeniem wspomagającym niektóre dziedziny medycyny (na przykład ortopedii, reumatologii, neurologii, chirurgii). Choroby zwyrodnieniowe układu ruchu są jedną z najczęstszych dolegliwości dzisiejszego starzejącego się społeczeństwa „siedzącego" (Okólski, Fihel 2012: 92-106). Zatem społeczna rola zawodu terapeuty manualnego jest duża i najprawdopodobniej będzie się zwiększała.

Uprawomocnienie pewnych metod leczniczych wymaga jednak ich potwierdzenia w badaniach, ponieważ dzisiejsza nauka oparta jest na dwóch rodzajach uniwersalnych języków - języku werbalnym oraz liczbowym. Problem z CCP polega na tym, że jest to kompetencja niezwykle subiektywna, związana z doznaniami sensorycznymi terapeuty. Jak już wspominano, jest to też dziedzina przynależna do wiedzy milczącej, co powoduje problem z przełożeniem jej na możliwą do intersubiektywnego komunikowania formę dyskursywną (na przykład podręczniki). Badanie CCP napotyka również bariery związane $\mathrm{z}$ tworzeniem norm liczbowych, kwantyfikacją i mierzeniem oddziaływania na ciało pacjenta poprzez różne 
formy dotyku i manipulacji tkanką. Trudno przeprowadzić eksperymentalną i laboratoryjną formę badania, ponieważ na terapię manualną wpływa określona budowa i fizjologia ciała pacjenta, jego dolegliwości, kondycja dnia terapeuty, stosowana siła nacisku, wrażliwość na to, co dzieje się w ciele pacjenta.

[...] nie mogę powiedzieć komuś, że słuchaj, „ty tego nie czujesz". Bo on tak samo może mi powiedzieć, że ja nie czuję tego. (O1)

[...] nasze czucie to jest tylko subiektywne uczucie. To nie da się tego nijak zmierzyć, jak ktoś coś czuje. Może być dziesięciu terapeutów, każdy będzie czuł coś innego. To nie znaczy, że któryś z nich czuje źle, tylko inaczej. (O9)

Wszystko to powoduje, że rożne działania wchodzące w zakres CCP są częścią bardzo złożonej sytuacji, na którą składają się działania terapeuty, reakcje pacjenta, mikroświat procesów biologicznych oraz przestrzeń, w której odbywa się terapia.

Trudność naukowego badania technik terapii manualnej prowadzi do dylematu, czy można stosować techniki, które pomagają pacjentowi, ale które $\mathrm{w}$ ramach dominującej formy naukowości (kwantyfikacja, powtarzalne wyniki laboratoryjne, teksty w czasopismach naukowych) nie zostały wyjaśnione. Czy można pomagać, nie do końca wiedząc, jaki jest biologiczny mechanizm sprawiający, że pacjent czuje się lepiej? Innymi słowy, jest to konflikt pomiędzy standardami nauki (evidence-based medicine) a postawą nastawioną na dobro pacjenta (patient-centered medicine) (Bensing 2000).

Osteopaci wielokrotnie to mówią, czy ten manewr manualny leczy, czy leczę ja, czy to jakieś pole leczy, nie wiem, co leczy, ale to działa i jest powtarzalne. I wiele metod osteopatycznych miało taką historię i część z nich wciąż ma taką. Ta historia się dalej pisze, bo metody nie wiadomo, jak działają, ale wyniki są powtarzalne. (O8)

Z jednej strony zadowoleni pacjenci wychodzący z gabinetu są najlepszą wizy tówką społecznej przydatności terapeutów manualnych. Z drugiej strony brak legitymizacji własnych działań w sposób naukowy sprawia, że pewne techniki i nurty terapii manualnej mogą być klasyfikowane na pograniczu medycyny alternatywnej i konwencjonalnej (np. osteopatia), co może powodować obniżenie statusu fizjoterapii i szkół terapii manualnej, które są z nią powiązane.

\section{Podsumowanie: pomiędzy tym, co konwencjonalne $i$ alternatywne}

Prezentowany tekst miał na celu pokazanie kategorii CCP jako przykładu obszaru badania wiedzy niedyskursywnej. Opisy CCP powinny być traktowane jako jego językowe formy reprezentacji. Należy w tym przypadku zastanowić się, czy w ogóle powinniśmy definiować cel badań wiedzy niedyskursywnej jako próbę wyjścia poza ograniczającą językową formę. W szczególności w obliczu wymogów tworzenia tekstów w formie pisanej, być może należałoby traktować badania wiedzy dyskursywnej w podobny sposób do przyjętego w prezentowanym tekście, czyli jako próbę szukania granic tego, co da się powiedzieć lub napisać na temat rzeczywistości pozajęzykowej. W takim przypadku dyskursywne metody jakościowe, uzupełnione metodami opartymi na wielozmysłowym dostępie do wiedzy (np. autoetnografii), mogą zostać poddane rewaloryzacji (a nie krytyce) jako użyteczne instrumenty badawcze. 
Aby poddać intersubiektywizacji CCP, konieczne jest wspólne doświadczenie dotykowe. Dlatego badacz relacjonujący, czym jest CCP, staje się swoistym translatorem, osobą, która próbuje w możliwe najbardziej zbliżony, obrazowy sposób przekazać specyfikę rzeczywistości pozajęzykowej w formie językowej. Sceptycy takiego sposobu przedstawiania CCP mogą stwierdzić, że jest to "tylko” bycie tłumaczem. Natomiast ci, którzy będą doszukiwali się pozytywnej strony takiego podejścia, mogą uznać, że niewątpliwą wartością tekstu jest przystępne zaprezentowanie laikom, na czym polega CCP i praca terapeuty manualnego.

W prezentowanym tekście pojawiła się dodatkowo druga warstwa translacji, poprzez którą próbowano pokazać pomosty między językiem nauk społecznych i nauk o zdrowiu. Taka optyka sprawia, że prezentowany tekst czytelnicy powinni traktować jako próbę ograniczania trzech typów dychotomii. Pierwszą z nich jest dychotomia pomiędzy naukami społecznymi a medycznymi. CCP zostało pokazane jako obszar, w którym potencjał uzyskują metody, pojęcia i perspektywa nauk społecznych. Prowadzi nas to do drugiej opozycji, jaką jest podział między metodami dyskursywnymi a tymi, które opierają się na wielozmysłowym doświadczeniu oraz ucieleśnieniu wiedzy. Badanie CCP wskazuje, że powinniśmy traktować je jako wzajemnie siebie uzupełniające. Trzecia dychotomia dotyczy opozycji między wiedzą dyskursywną i niedyskursywną. Na poziomie analitycznym jest to użyteczne rozróżnienie. Niemniej jednak przykład terapeutów manualnych wskazuje, że na poziomie praktycznym (leczenia) oraz edukacyjnym (przekazywania wiedzy) rozróżnienie to jest problemem do rozwiązania. Sposoby przedstawiania, czym jest CCP oraz jak się je rozwija i przekazuje są dobitnym przykładem doświadczeń w zacieraniu granic między dwoma przedstawianymi światami wiedzy. Terapeuci manualni radzą sobie z tymi ograniczeniami poprzez wykorzystanie metod wizualnych w formie wykresów, zdjęć, używanie barwnych porównań i opisów w formie metafor, stosowanie przedmiotów podczas terapii, ciągłe przechodzenie między wiedzą z kursów a doświadczeniem zakorzenionym we własnej praktyce badawczej, stosowanie pokazów oraz innych metod przedstawianych w rozdziale Kilka praktycznych sposobów przekazywania CCP.

Takie działanie ma swoje konkretne konsekwencje społeczne w postaci udoskonalania praktyk edukacyjnych, tłumaczenia otoczeniu społecznemu specyfiki własnej profesji oraz udoskonalania systemów leczenia pacjentów. Stąd należy uznać, że konieczność dalszego pogłębiania wiedzy na temat CCP jest uwarunkowana nie tylko wymogami teoretycznymi, ale również praktycznymi. Z punktu widzenia różnych nurtów terapii manualnej najważniejszy jest ostateczny efekt, ponieważ fizjoterapia i inne szkoły wywodzące się z niej są dyscyplinami z pewną misją, jaką jest leczenie ludzi, pomaganie im $\mathrm{w}$ osiąganiu zadowalającego stopnia sprawności. Ostatecznie jednak to określony terapeuta ze swoimi specyficznymi umiejętnościami CCP zostaje sam z określonym pacjentem, z jego specyficzną konstrukcją psycho-fizyczną. $W$ momencie, gdy trzeba kontekstualnie zastosować nabytą wiedzę, znaczenia nabierają stwierdzenia "fach w ręku” lub „myślenie ręką". Podczas terapii nieuchronnie pojawia się dotyk terapeuty. To właśnie wtedy głowa, umysł oraz ciało terapeuty, jego ręce, stają się jednym systemem integrującym różne rodzaje wiedzy, których celem jest wyleczenie pacjenta. To właśnie wtedy język teorii łączy się w jedność z językiem praktyki i językiem ciała. Wiedza niedyskursywna jest nieodłączną częścią pewnych profesji społecznych i wypełnianych przez nie ról. Nie można jej 
konfrontować na zasadzie prostej opozycji z dyskursywnymi formami wiedzy. Pomiędzy wiedzą czysto teoretyczną (na przykład przekazywaną w podręcznikach anatomii, fizjologii), skodyfikowaną wiedzą praktyczną nastawioną na osiągnięcie jakiegoś celu (na przykład podręczniki do anatomii palpacyjnej, podręczniki określonych szkół terapeutycznych; w innych dziedzinach poradniki dietetyczne, książki na temat technik sprzedaży) a wiedzą opartą na praktyce (na przykład kompetencja CCP w zawodzie fizjoterapeuty) istnieje kontinuum. Można uznać, że praktyka w zawodzie fizjoterapeuty, i zapewne w wielu innych profesjach, to ciągłe zamazywanie tych granic pomiędzy określonymi systemami wiedzy, uspójnianie ich, tworzenie pomostów pomiędzy nimi. Dlatego też przypadek CCP jest interesujący, ponieważ dowodzi, że nawet w świecie medycyny głównego nurtu, opartej na restrykcyjnych standardach obiektywności i kwantyfikacji, istnieje miejsce na niedyskursywne formy

\section{Bibliografia}

Bensing Jozien (2000) Bridging the gap. The separate worlds of evidence-based medicine and patient-centered medicine. "Patient Education and Counseling", vol. 39, s. 17-25.

Biel Andriew (2018) Przewodnik po ścieżkach ciała. Anatomia palpacyjna. Przełożył Mariusz Kurkowski. Konarzyce: S3 Publishing.

Bringley Amanda (2012) Touching Space in Hurt and Healing: Exploring Experiences of Illnes and Recovery Through Tactile Art [w:] Mark Paterson, Martin Dodge, eds., Touching Space, Placing Touch. Burlington: Ashgate, s. 71-88.

Bukraba-Rylska Izabela (2017) Socjologia ciała, czyli (póki co) teorie dekoracyjne. „Studia Socjologiczne”, nr 4, s. 189-208.

Chaitow Leon, Fritz Stanley (2007) Masaż leczniczy. Bóle dolnego odcinka kręgosłupa i miednicy. Przełożył Rafał Gnat, Mirosław Kokosz. Wrocław: Urban \& Partner. wiedzy. CCP sprawia, że znaczenia nabiera ciało terapeuty i jego subiektywne odczucia w kontraście do terapii lekowych i obiektywnych metod badania stanu zdrowia (na przykład badania krwi, moczu, USG). Nieuchronnie CCP wprowadza też problemy filozoficzne związane ze znaczeniem wiary w procesie leczniczym. CCP również problematyzuje klasyfikacje, granice i dychotomie pomiędzy medycyną konwencjonalna a alternatywną. „Alternatywne” podejście do leczenia ciała jest często traktowane przez medycynę głównego nurtu jako negatywny punkt odniesienia, pokazujący, czym ona nie jest, jakiej etyki powinna się wystrzegać. Niemniej jednak skuteczność niektórych form terapii manualnej, które jeszcze nie zostały w satysfakcjonujący sposób naukowo wyjaśnione, pokazuje, że granice te nie powinny być traktowane sztywno, ponieważ świat „alternatywności”, i często związanej z nią niedyskursywności, może być również rezerwuarem nowych metod leczenia i innowacji medycznych.

Gąsior Paweł (2015) Elementy kształcenia ruchowego i metodyki nauczania ruchu: skrypt dla studentów fizjoterapii. Nowy Targ: Podhalańska Państwowa Wyższa Szkoła Zawodowa.

Howes David (2005) Skinscapes. Embodiment, Culture, Environment [w:] Constance Classen, ed., The Book of Touch. Oxford, New York: Berg Publishers, s. 27-39.

Jakubowska Honorata (2015) Wiedza pozadyskursywna i sposoby jej badani na przykładzie przekazywania i nabywania sportowych umiejętności. „Studia Socjologiczne”, nr 3, s. 173-191.

Jakubowska Honorata (2017) Skill Transmission, Sport and Tacit Knowledge. A Sociological Perspective. London, New York: Routlege.

Kaufmann Jean-Claude (2004) Ego - socjologia jednostki. Inna wizja człowieka i konstrukcji podmiotu. Przełożył Krzysztof Wakar. Warszawa: Oficyna Naukowa. 
Krajewski Marek (2005) Kultury kultury popularnej. Poznań: UAM.

Kvale Steinar (2004) Interviews. Wprowadzenie do jakościowego wywiadu badawczego. Przełożył Stanisław Zabielski. Białystok: TransHumana.

Lowen Alexander (1991) Duchowość ciała. Przełożył Stefan Sikora. Warszawa: Agencja Wydawcza Jacek Santorski \& CO.

Lowen Alexander (2011) Przyjemność. Kreatywne podejście do życia. Przełożył Paweł Luboński. Warszawa: Czarna Owca.

Mauss Marcel (2001) Socjologia i antropologia. Przełożyli Marcin Król, Krzysztof Pomian, Jerzy Szacki. Warszawa: KR.

Merton Robert (1972) Insiders/Outsiders: A Chapter in the Sociology of Knowledge. „American Journal of Sociology”, vol. 78, no. 1, s. 9-47.

Obrador Pau (2012) Touching the Beach [w:] Mark Paterson, Martin Dodge, eds., Touching Space, Placing Touch. Burlington: Ashgate, s. $47-70$.

Okólski Marek, Fihel Agnieszka (2012) Demografia. Wspótczesne zjawiska i teorie. Warszawa: Scholar.
Paterson Mark (2009) Haptic Geographies: Etnography, Haptic Knowledges and Sensous Dispositions. "Progress in Human Geography", vol. 33, no. 6, s. 766-788.

Polanyi Michael (1966) The Tacit Dimension. Chicago: University of Chicago Press.Sennett Richard (2010) Etyka dobrej roboty. Przełożył Jan Dzierzgowski. Warszawa: MUZA S.A.

Schleip Robert (2018) Przedmowa do wydania polskiego [w:] Biel Andriew, Przewodnik po ścieżkach ciała. Anatomia palpacyjna. Przełożył Mariusz Kurkowski. Konarzyce: S3 Publishing.

Tixa Serge (2008) Atlas anatomii palpacyjnej. Badanie manualne powłok. T. 1 Szyja, tułów i kończyna górna. Przełożyła Joanna Józefowicz-Pacuła. Warszawa: PZWL.

Typaldos Stephen (2002) FDM. Clinical and Theoretical Application of the Fascial Distortion Model Within the Practice of Medicine and Surgery. Berrien Springs: Typaldos Publishing.

Vannini Phillip, Waskul Dennis D. ,Gottschalk Simon (2012) The Senses in Self, Society and Culture. A Sociology of Senses. New York: Routlege.

\section{Cytowanie}

Modrzyk Ariel (2020) Wiedza w ręku. Wiedza niedyskursywna i czucie ciała pacjenta w zawodzie terapeuty manualnego. „Przegląd Socjologii Jakościowej", t. 16, nr 2, s. 128-150 [dostęp dzień, miesiąc, rok]. Dostępny w Internecie: «www.przegladsocjologiijakosciowej.org>. DOI: http://dx.doi.org/10.18778/1733-8069.16.2.08

\section{Knowledge in Hand. Non-Discursive Knowledge and Feeling the Patient's Body in the Profession of a Manual Therapist}

Abstract: A sense of the patient's body as a part of the profession of manual therapists is a subject related to the concept of non-discursive knowledge. The main goal of the article is to familiarize the reader with these issues as a certain bridge that allows for an interdisciplinary link between social sciences and health sciences. Above all, this aim assumes spreading awareness of the existence of a certain component of physiotherapeutic knowledge, which - contrary to the requirements of the dominant in medical sciences objectified form of the presentation of knowledge and researches -does not easily subject to quantification and explanation in linguistic terms. Thus, along with this assumption, the most important points of references for this article include: sensitizing to barriers encountered by researches who try to study the phenomenon of feeling the patient's body by using qualitative methods; presenting what the competence of feeling the patient's body means; revealing how this competence is taught and acquired; and showing how it addresses the dominant scientific standards in medical sciences.

Keywords: non-discursive knowledge, touch, manual therapists, physiotherapy, qualitative methods 